\title{
Range extension of dendrobatid frog Colostethus ruthveni Kaplan, 1997 (Anura: Dendrobatidae) in the Sierra Nevada de Santa Marta, Colombia
}

\author{
Hernán Darío Granda-Rodríguez ${ }^{1,3^{*}}$, Liliana Patricia Saboyá-Acosta ${ }^{2}$, Adolfo del Portillo-Mozo $^{3}$ and \\ Juan Manuel Renjifo ${ }^{2}$ \\ 1 University of Costa Rica, School of Biology, Postgraduate program in Biology, 2060, San Jose, Costa Rica. \\ 2 University of Magdalena, Research Group in Systematic and Ecology of Amphibians and Reptiles, Carrera 32 No 22-08, 2-1-216304, Santa Marta, \\ Colombia. \\ 3 University of Magdalena, Research Group in Environmental Impact and Conservation of Flora and Fauna, Carrera 32 No 22-08, 2-1-216304, Santa \\ Marta, Colombia. \\ * Corresponding author. E-mail: hernangrandar@gmail.com
}

\begin{abstract}
The endemic dendrobatid, Colostethus ruthveni is first reported in the rivers Buritaca, Frío and Piedras from northwestern side of the Colombian Sierra Nevada de Santa Marta and Nabusimake Village in the southeastern side of this massif. The present new reports allow extend the geographical distribution of $C$. ruthveni to other areas of the Sierra Nevada de Santa Marta where it had not been reported. Our finding suggests that current geographical distribution of this anuran is underestimated. Populations of this anuran are considered endangered (IUCN 2013).
\end{abstract}

DOI: $10.15560 / 10.3 .674$

The Sierra Nevada de Santa Marta (SNSM) is a mountain range isolated from the Andes in the north of Colombia. Its geomorphology and climate provide adequate conditions to coexistence of many endemic species, which have evolved in a limited spatial area (Carbonó and LozanoContreras 1997). According to recent estimations, this area concentrates a high level of amphibian endemism with approximately 19 species from high altitudes (Fundación Pro-Sierra Nevada de Santa Marta 1998). However, current political status of the SNSM, which is frequently threatened by paramilitary and guerrilla, has obstructed the obtaining of information about most of amphibian species that inhabit this important ecosystem.

The representative endemic dendrobatid from SNSM is Colosthethus ruthveni Kaplan, 1997. This species is a diurnal small to medium frog size (18.9-20.1 SVL for males and 19.8-24.1 SVL for females), with a cryptic color pattern. This frog is commonly found in the northwestern slope of the massif, from 680 to $1,500 \mathrm{~m}$ a.s.l. (Kaplan 1997; Lynch et al. 2004). The IUCN categorizes this species as endangered (EN) because its distribution occurs in an area smaller than $5000 \mathrm{Km}^{2}$, and also individuals are found in only less than five localities in the Sierra Nevada de Santa Marta (IUCN 2013).

We recorded a total of 118 individuals of Colosthethus ruthveni from different surveys in 2007 and 2012. We collected data in six localities from the north side in the rivers "Buritaca" (Don Adán - Teyuna), "Gaira" (La Victoria), "Río Frío" (San Pedro de la Sierra), "Donama" in the village of Bonda (Santa Marta), and "Las Tinajas" near the Tayrona Park and one locality from southeastern region in Nabusimake (Table 1). Individuals measured had a SVL mean of $19.37 \pm 1.73 \mathrm{~N}=31$ (Males $19.44 \pm 1.21, \mathrm{~N}=19$; females 20.15 $\pm 1.07, \mathrm{~N}=10$ ). Males were mainly found in rocks and wood trunks, while females were located in litter leaf and soil. In general, this species was commonly found in stream banks in areas of relatively open canopy. Colosthethus ruthveni was closely associated with water bodies, being its perches (microhabitats) localized close to hard bottom, leaf litter, fallen logs, soil near stream and leaves of shrubs. We collected four specimens in Las Tinajas and La Victoria, which were deposited in the Herpetological Collection of University of Magdalena (CBUMAG:ANF: 668, 971, 992, 1679). For others localities (Río Buritaca, Nabusimake, Río Piedras and Rio Frío) we take high-resolution photographs that allow us to accesses morphological diagnostic features to identify the species (Figure 1A-D). Colosthethus ruthveni differs from others members of this genus by having two narrow dorsolateral stripes on flanks: a pale yellow one in upper part and a dark in life; limbs slender with basal webbing on feet, absent on hands; discs of fingers and toes expanded; wide brown bands across thighs with a pale region between that bands and the cloacal region, dorsal, head, and limbs skin smooth, except for small granules in lumbar region, pericloacal region, and proximal part of posterior surfaces of thighs in some individuals (Kaplan 1997).

According to Lynch et al. (2004), Colostethus ruthveni is distributed from 680 to $1,540 \mathrm{~m}$ a.s.l. We have found some individuals $(\mathrm{N}=10)$ in the northwestern slope of Sierra Nevada de Santa Marta at $472 \mathrm{~m}$ a.s.l. which extends the altitudinal range of $C$. ruthveni toward low altitudes (see Table 1). Besides the record of Kaplan (1997) in the area of "La Tagua" (Basin of the River Toribio), C. ruthveni had been reported in "Quebrada Rodríguez" area of Neguanje (Tayrona Park) (Rueda-Solano and Castellano-Barliza 
TABLE 1. Occurrence sites of Colostethus ruthveni in Colombia from literature and recorded in this study.

\begin{tabular}{|c|c|c|c|c|c|c|}
\hline SITE & DEPARTMENT & GEOREFERENCE & $\begin{array}{l}\text { ALTITUDE } \\
\text { (M A.S.L) }\end{array}$ & DATE & REFERENCE & $\begin{array}{c}\text { NO. } \\
\text { INDIVIDUALS }\end{array}$ \\
\hline $\begin{array}{l}\text { West Mountains of San Miguel } \\
\text { and Don Diego }\end{array}$ & Santa Marta, Magdalena & Not available & $680-1540$ & Not available & $\begin{array}{l}\text { Kaplan, 1997, } \\
\text { Ruthven } 1922\end{array}$ & Not available \\
\hline Neguanje & Santa Marta, Magdalena & Not available & $0-750$ & $\begin{array}{l}\text { September- } \\
\text { October } 2004\end{array}$ & $\begin{array}{l}\text { Rueda-Solano } \\
\text { and Castellano- } \\
\text { Barliza, } 2010\end{array}$ & Not available \\
\hline Námaku & Santa Marta, Magdalena & $\begin{array}{l}11^{\circ} 6^{\prime} 44.47^{\prime \prime} \mathrm{N} \\
74^{\circ} 8^{\prime} 43.27^{\prime \prime} \mathrm{W}\end{array}$ & $737-923$ & $\begin{array}{l}\text { January and } \\
\text { March } 2010\end{array}$ & $\begin{array}{l}\text { González-Maya } \\
\text { et al. } 2011\end{array}$ & Not available \\
\hline San Pedro ${ }^{\star}$ & Ciénaga, Magdalena & $\begin{array}{l}10^{\circ} 53^{\prime} 42,7^{\prime \prime} \mathrm{N} \\
74^{\circ} 5^{\prime} 22.07^{\prime \prime} \mathrm{W}\end{array}$ & 1414 & $\begin{array}{l}\text { March } 19^{\text {th }} \text { to } 24^{\text {th }} \\
2007\end{array}$ & Present study & 15 \\
\hline Nabusimake & Pueblo Bello, Cesar & $\begin{array}{l}10^{\circ} 30^{\prime} 56.08^{\prime \prime} \mathrm{N} \\
73^{\circ} 20^{\prime} 31.75^{\prime \prime} \mathrm{W}\end{array}$ & $2100^{-}$ & $\begin{array}{l}\text { May } 11^{\text {th }} \text { to } 14^{\text {th }} \\
2008\end{array}$ & Present study & 10 \\
\hline La Victoria* & Santa Marta, Magdalena & $\begin{array}{c}11^{\circ} 7^{\prime} 24.46^{\prime \prime} \mathrm{N} \\
74^{\circ} 5^{\prime} 27.62^{\prime \prime} \mathrm{W}\end{array}$ & 993 & April-June, 2010 & Present study & 5 \\
\hline Las Tinajas & Santa Marta, Magdalena & $\begin{array}{l}11^{\circ} 17^{\prime} 3.89^{\prime \prime} \mathrm{N} \\
74^{\circ} 4^{\prime} 0.09^{\prime \prime} \mathrm{W}\end{array}$ & 653 & $\begin{array}{l}\text { July } 23 \text { th to } 25^{\text {th }} \\
2010\end{array}$ & Present study & 26 \\
\hline Tezhumake-Ciudad Perdida* & Santa Marta, Magdalena & $\begin{array}{l}11^{\circ} 5^{\prime} 43.61^{\prime \prime} \mathrm{N} \\
73^{\circ} 53^{\prime} 45.56^{\prime \prime} \mathrm{W}\end{array}$ & 800 & $\begin{array}{l}\text { July } 7 \text { th to } 17 \text { th, } \\
2012\end{array}$ & Present study & 39 \\
\hline El Mamey-Don Adan* & Santa Marta, Magdalena & $\begin{array}{c}11^{\circ} 7^{\prime} 32.89^{\prime \prime} \mathrm{N} \\
73^{\circ} 51^{\prime} 24.63^{\prime \prime} \mathrm{W}\end{array}$ & 550 & $\begin{array}{l}\text { July } 22 \text { th to } 24 \text { th, } \\
2012\end{array}$ & Present study & 13 \\
\hline Donama $\bullet$ & Santa Marta, Magdalena & $\begin{array}{l}11^{\circ} 14^{\prime} 09.3^{\prime \prime} \mathrm{N} \\
74^{\circ} 02^{\prime} 53.0^{\prime \prime} \mathrm{W}\end{array}$ & 472 & $\begin{array}{l}\text { October } 10^{\text {th }} \text { to } \\
13^{\text {th }}, 2012\end{array}$ & Present study & 10 \\
\hline
\end{tabular}

\ Río Frío watershed, • Río Gaira watershed * Buritaca watershed, • Río Piedras watershed $\bullet$ New records at high altitudes.

2010) and in Námaku private reserve near Minca Village (Santa Marta) (González-Maya et al. 2011); all places are in the northwestern slope of SNSM. Similarly, our results extend the geographical distribution of $C$. ruthveni to the southeastern slope of Sierra Nevada de Santa Marta, and add new reports for the Basins of "Río Buritaca", "Río Frío" and "Río Piedras" on the Northern area. Additionally, we present records from "Las Tinajas" close to the Tayrona
Park, "Donama" (Basin of "Río Piedras") and "La Victoria" in the city of Santa Marta (Basin of "Río Gaira") (Figure 2). In Nabusimake the species was recorded at 2,100 m a.s.l, following the observations described by Ruthven (1922) (elevation above 2,000 $\mathrm{m}$ a.s.l. Accordingly, the new records provide valuable insights into the distribution of this frog and could assist future sustainable management of this species in the Sierra Nevada de Santa Marta.
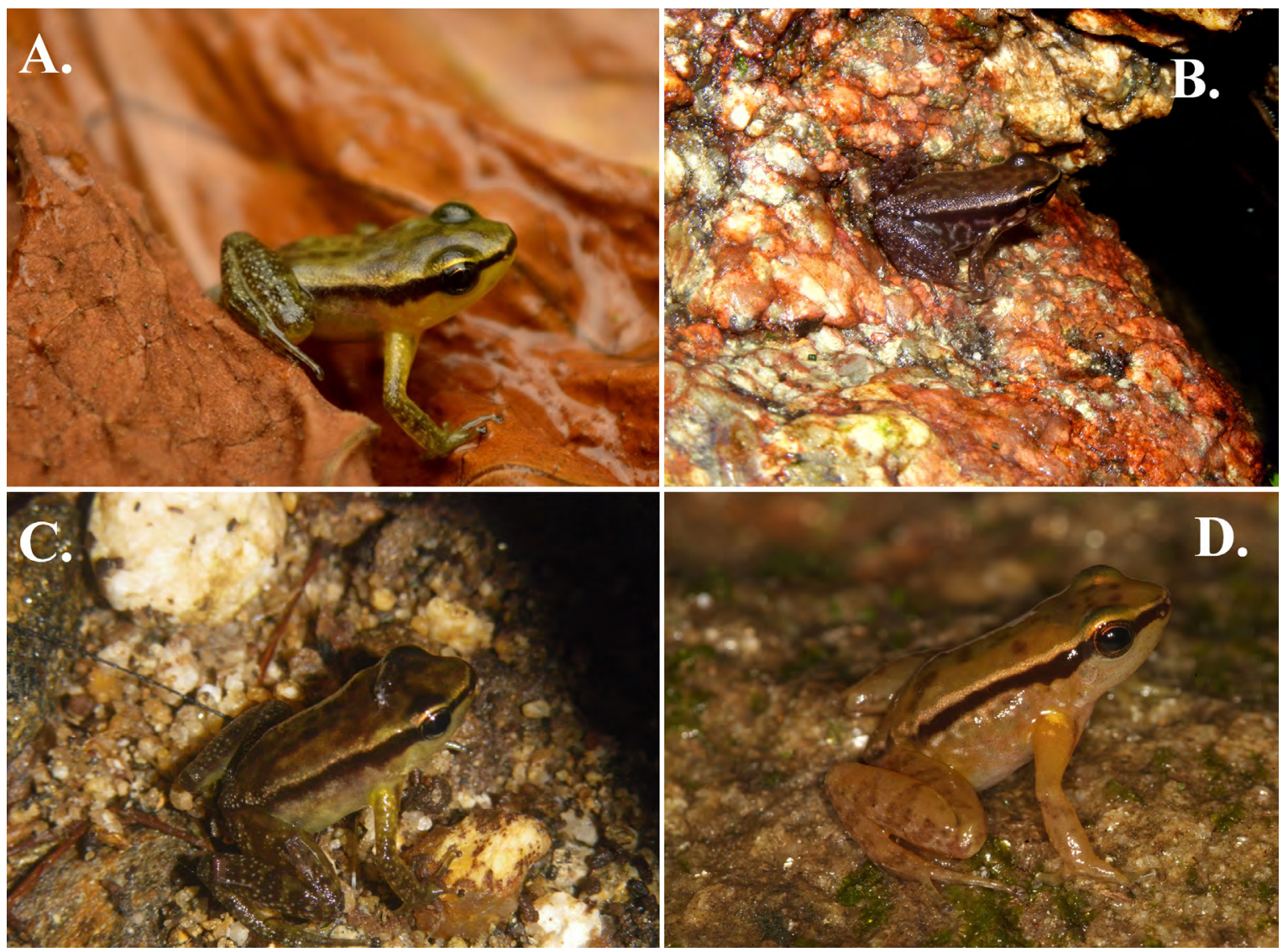

Figure 1. Images of the species Colostethus ruthveni in its habitat. A. Río Buritaca (Photograph by Liliana Saboyá). B. Nabusimake (Photograph by Hernan Granda) C. Río Piedras. (Photograph by Liliana Saboyá) D. Río Frío (Photograph by Juan Manuel Renjifo). 

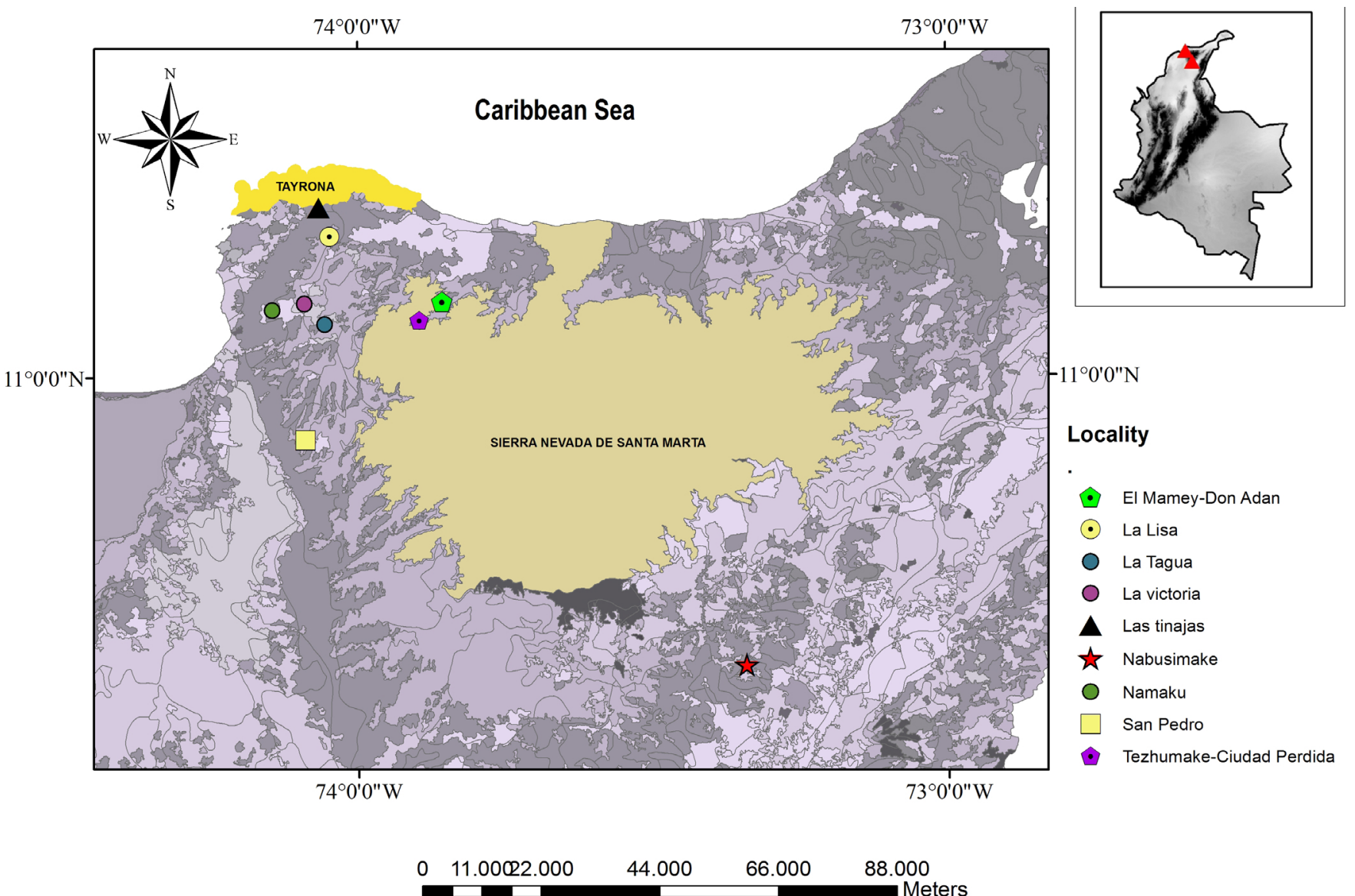

FiguRE 2. Study area. Current known distribution and recent records of Colostethus ruthveni in Sierra Nevada de Santa Marta, Colombia.

ACKNOWLEDGments: We express our gratitude to Fundación Selva and Fundación de Investigaciónes Arqueologicas y Ambientales Tayrona (FIAAT) by share the Buritaca data from the project: The biodiversity of the Buritaca River watershed. This research was supported by the fellowship "Jovenes Investigadores e Innovadores Virginia Gutierrez Pineda", given by Colciencias, Colombia. Also thanks to Patricio Hernáez, Miguel Cantillo, Victor Acosta, Roberto Quiros, Amandine Bourg for the early revision of the manuscript.

\section{LITERATURE CITED}

Carbonó, E and G. Lozano-Contreras. 1997. Endemismos y otras singularidades de la Sierra Nevada de Santa Marta, Colombia. Posibles causas de orígenes y necesidades de Conservarlos. Revista de la Academia de Ciencias Exactas, Física y Naturales 21(81): 409419 (http://www.accefyn.org.co/revista/Vol_21/81/409-419.pdf).

Fundación Pro-Sierra Nevada de Santa Marta. 1998. Evaluación Ecológica Rápida de la Sierra Nevada de Santa Marta. Definición de Áreas Críticas Para La Conservación en la Sierra Nevada de Santa MartaColombia. Santa Marta, Fundación Pro-Sierra Nevada. Santa Marta. Ministerio del Medio Ambiente. UAESPNN. The Nature Conservancy USAID, Embajada de Japón. 135 pp.

González-Maya, J.F., M. González, D. Zárrate-Charry, F. Charry, A.A. Cepeda and S.A. Balaguera-Reina. 2011. A new population record and conservation assessment of the Santa Marta Poison Arrow Frog
Colostethus ruthveni Kaplan, 1997 (Anura: Dendrobatidae) from Sierra Nevada de Santa Marta, Colombia. Journal of Threatened Taxa 3(3): 1633-1636 (http://threatenedtaxa.org/ZooPrintJournal/2011/ March/o251326iii111633-1636.pdf).

Kaplan, M. 1997. A New species of Colostethus from Sierra Nevada de Santa Marta (Colombia) with comments on intrageneric relationships within the dendrobatidae. Journal of Herpetology 31(3): 369-375.

Lynch J., M.P. Ramírez Pinilla, M. Osorno-Muñoz, J. Vicente Rueda, A. Amézquita and M.C. Ardila-Robayo. 2004. Colostethus ruthveni. In IUCN 2010. IUCN Red List of Threatened Species. Version 2010.1. Accessible at http//www.iucnredlist.org. Captured on 3 June 2013.

Rueda-Solano, L.A. and J. Castellanos-Barliza. 2010. Herpetofauna de Neguanje, Parque Nacional Natural Tairona, Caribe colombiano. Acta Biológica Colombiana 15(1): 195-206 (http://www.revistas.unal. edu.co/ojs/index.php/actabiol/article/view/9895/15280)

Ruthven, A.G. 1922. The amphibians and reptiles of the Sierra Nevada de Santa Marta. Miscellaneous Publications Museum of Zoology University of Michigan No.8: 1-94 pp.

RECEIVED: February 2014

ACCEPTED: May 2014

Published ONLINE: July 2014

EDITORIAL RESPONSIBILITY: NATAN MEDEIROS MACIEL 